\title{
TGF- $\beta$ in fibrosis by acting as a conductor for contractile properties of myofibroblasts
}

\author{
Alexandre Vallée ${ }^{1,2^{*}}$ and Yves Lecarpentier ${ }^{3}$
}

\begin{abstract}
Myofibroblasts are non-muscle contractile cells that play a key physiologically role in organs such as the stem villi of the human placenta during physiological pregnancy. They are able to contract and relax in response to changes in the volume of the intervillous chamber. Myofibroblasts have also been observed in several diseases and are involved in wound healing and the fibrotic processes affecting several organs, such as the liver, lungs, kidneys and heart. During the fibrotic process, tissue retraction rather than contraction is correlated with collagen synthesis in the extracellular matrix, leading to irreversible fibrosis and, finally, apoptosis of myofibroblasts. The molecular motor of myofibroblasts is the non-muscle type IIA and B myosin (NMMIIA and NMMIIB). Fibroblast differentiation into myofibroblasts is largely governed by the transforming growth factor- $\beta 1$ (TGF- $\beta 1$ ). This system controls the canonical WNT/ $\beta$-catenin pathway in a positive manner, and PPARY in a negative manner. The WNT/ $\beta$-catenin pathway promotes fibrosis, while PPAR prevents it. This review focuses on the contractile properties of myofibroblasts and the conductor, TGF- $\beta 1$, which together control the opposing interplay between PPARY and the canonical WNT/ $\beta$-catenin pathway.
\end{abstract}

Keywords: Transforming growth factor- $\beta 1$, PPARY, Canonical WNT/- $\beta$-catenin, YAP/TAZ, Smad, Myofibroblasts, Fibrosis, Myosin

\section{Background}

Gabbiani et al. first reported the presence of modified fibroblasts or myofibroblasts in granulation tissue and its role in wound healing [1]. They showed that the modified fibroblasts presented contractile properties, shared some similarities with smooth muscle cells, and played a major role in wound contraction. In fact, it was observed as early as 1916 that the contraction-retraction process is an important factor in the repair of tissue injury [2]. The active retraction of granulation tissue in a wound is due to non-contractile muscle cells known as myofibroblasts [3]. Transforming growth factor- $\beta 1$ (TGF- $\beta 1$ ) acts on the dual antagonism system comprising the canonical WNT/ $\beta$-catenin and peroxisome proliferator activated receptor gamma (PPAR $\gamma)$. These two signaling systems act in an opposite manner in several pathological conditions [4-12]. Thus, when the expression of PPARy is increased,
WNT/ $\beta$-catenin signaling is decreased, while when $\mathrm{WNT} / \beta$-catenin signaling is increased, PPAR $\gamma$ expression is decreased $[11,13]$. Myofibroblast differentiation is controlled by TGF- $\beta 1$, which activates canonical WNT signaling and decreases PPAR $\gamma$ expression [14].

Fibroblasts and myofibroblasts are the main effectors involved in the initiation of fibrosis due to excessive collagen deposition and an inappropriate extracellular matrix (ECM). TGF- $\beta 1$ activation leads to the differentiation of fibroblasts into contractile myofibroblasts, expression of $\alpha$-smooth muscle actin ( $\alpha$-SMA) and the synthesis of proteins of the extracellular matrix such as collagen. This review focuses on homeostasis and the contractile properties of myofibroblasts in physiological and pathophysiological states, mainly in the fibrosis process. The study is mainly based on the role of the opposite conductor TGF $\beta 1$ on both PPAR $\gamma$ and the canonical WNT/ $\beta$ catenin pathway.

\footnotetext{
*Correspondence: alexandre.g.vallee@gmail.com

${ }^{2}$ DACTIM-MIS, Laboratoire de Mathématiques et Applications (LMA),

CNRS, UMR 7348, Université de Poitiers, CHU de Poitiers, Poitiers, France

Full list of author information is available at the end of the article
} 


\section{Myofibroblasts}

According to the first descriptions, the major structural characterization of contractile myofibroblasts is the presence of actin filament bundles containing $\alpha$-SMA, peripheral focal adhesions and adjoining myofibroblast junctions composing the granulation tissue $[1,15]$. Soon after injury, local fibroblasts called proto-myofibroblasts translate into the core of the wound. Thus, proto-myofibroblasts differentiate into myofibroblasts containing $\alpha$-SMA, leading to wound retraction [16]. Proto-myofibroblasts contain type I and III collagen and fibronectin EDA, which is indispensable for the differentiation of myofibroblasts [17]. After closing the wound, myofibroblasts disappear by apoptosis [18].

The origins of myofibroblasts are multiple [19]. Mesenchymal stem cells (MSCs) and fibroblasts, which are the precursors of proto-differentiated myofibroblasts, have been observed in physiological tissues such as the alveolar septa of the lung, uterine submucosa, lymph nodes, spleen, the renal capsule, the periodontal ligament, intestinal crypts and stromal bone marrow. In general, fibroblast differentiation into myofibroblasts occurs during the skin repair process following injury, during the fibrotic process in the liver, skin, kidneys, heart and lungs and in the stroma of cancers. In the granulation tissue, myofibroblasts induce remodeling of the ECM and then promote wound healing [20]. However, the aberrant wound healing sometimes leads to a proliferation of myofibroblasts. Their differentiation can be triggered by multiple cell pathways [21]. Growth factors are usually carried in the ECM. They are stimulated and then released by mechanical stress or proteolytic cleavage. Then, they migrate to bind to membrane receptors. This phenomenon leads to activation of the intracellular complexes that migrate to the nucleus, thus promoting the transcription or repression of target genes that are involved in fibrosis.

Myofibroblasts have been observed in several fibrosis processes, including systemic sclerosis (SSc), glomerulosclerosis, idiopathic pulmonary fibrosis, liver cirrhosis, heart failure and myocardial infarction [22]. Myofibroblasts have also been observed in the stroma in epithelial cancers [23], retinal detachments [24] and human capsular cataracts [25]. Chronic injury causes prolonged stimulation of fibroblasts [26] for the differentiation into myofibroblasts. Myofibroblasts could remain after the closure of a wound, which results in a hypertrophic scar, especially after burns [27]. Myofibroblasts may be found in coronary plaques [28]. Precursors of myofibroblasts are stellate cells in the liver [29], pericytes in the kidneys [30] and fibrocytes derived from bone marrow [31]. Lines of non-fibroblast cells $[32,33]$ can differentiate into myofibroblasts through the epithelial-mesenchymal transition
[34] and the endothelial-mesenchymal transition [35]. MSCs are precursors of myofibroblasts in several diseases [36]. A major case is the presence of myofibroblasts in physiological human placenta, a tissue in which contractile myofibroblasts constitute the majority of the placental stem villi [37]. In normal human placenta, the differentiation of fibroblasts into myofibroblasts occurs from the peripheral part of the stem villi towards its main part. Fibroblast differentiation into myofibroblasts requires the participation of complex chemical and physical factors. Among these are the augmentation index of stiffness of the studied tissues [16] and TGF- $\beta 1$ with fibronectin EDA [17]. TGF- $\beta 1$ increases $\alpha$-SMA synthesis leading to myofibroblast differentiation. Incorporation of $\alpha$-SMA in stress fibers stimulates the contractile properties of myofibroblasts [38]. ECM enables the transmission of the contractile force, enhanced by $\alpha$-SMA and the myosin molecular motor through focal adhesions containing transmembrane integrins [39]. In ECM, TGF- $\beta 1$ is released by a mechanical, integrin-dependent process [27]. Moreover, the availability of TGF- $\beta 1$ is stimulated by the rigidity of the ECM [40].

\section{Myofibroblasts are contractile cells}

There are two types of contractile cells, i.e. contractile muscle cells and non-muscle cells. All the contractile cells act by means of a myosin molecular motor, which is associated with $\alpha$-SMA. The molecular motors are type I and type II muscle myosins (MMI and II) in muscle cells (smooth muscles and striated sarcomeric muscles) and type II non-muscle myosins (NMMII) in non-muscle contractile cells [41]. NMMII is involved in cell polarity generation, cell migration and cell-cell adhesion. The molecular motor is the non-muscle myosin IIA and B (NMMIIA and B). NMMIIA is largely dominant in myofibroblasts and predominates in the extravascular part of normal human placental stem villi [42]. Myofibroblasts are also observed in numerous pathophysiological tissues, including cancer (breast carcinoma, epithelial cells of cancerous mammary glands) and in fibrotic processes (Dupuytren nodules, hypertrophic scars) [43].

As with MMII, NMMII contains three pairs of chains: one pair of heavy chains and two pairs of light chains that regulate and stabilize the heavy chain structure. Two main systems regulate NMMII activity: first, the calciumcalmodulin-myosin light chain kinase (MLCK); secondly, the Rho/ROCK/myosin light chain phosphatase [44].

NMMIIA binds to actin in the head of the heavy chain. Myosin filaments link actin filaments and the NMMIIA molecules assemble into bipolar filaments [41]. This allows the myosin to slide along the actin filaments. A bend in the head also enables a conformational change in the actin filaments so that they are no longer operating 
in a parallel manner, but are opposed to one another. The crossbridge (CB) actin-myosin cycle is very similar to that observed in the myosin of smooth and striated muscles. An ATP molecule binds with the NMMIIA-ATPase site on the myosin head. This enables the dissociation of actin from the NMMIIA head. Then, the ATP is hydrolyzed and the NMMIIA is able to bind with actin. Thus, the binding process results in a bend in the NMMIIA head, leading to the creation of a single $\mathrm{CB}$ force (order of magnitude: few picoNewtons) and a displacement of a few nanometers. The actin-NMMIIA complex then releases ADP. A new ATP molecule dissociates actin from the NMMIIA head, and a new $\mathrm{CB}$ cycle can begin (Fig. 1).

The main feature of NMMIIA is its extreme slowness. NMMIIA kinetics are extremely slow (Table 1) [45]. Compared to skeletal or smooth muscles, the constants of $\mathrm{CB}$ detachment and $\mathrm{CB}$ attachment, the catalytic constant, and myosin ATPase are low (Table 1). Nevertheless, the single force of one NMMIIA CB is of the same order of magnitude as that observed in smooth and striated muscles. The low isometric tension reported in placental stem villi [46] is explained by the low placental myosin content [47]. The extremely slow shortening

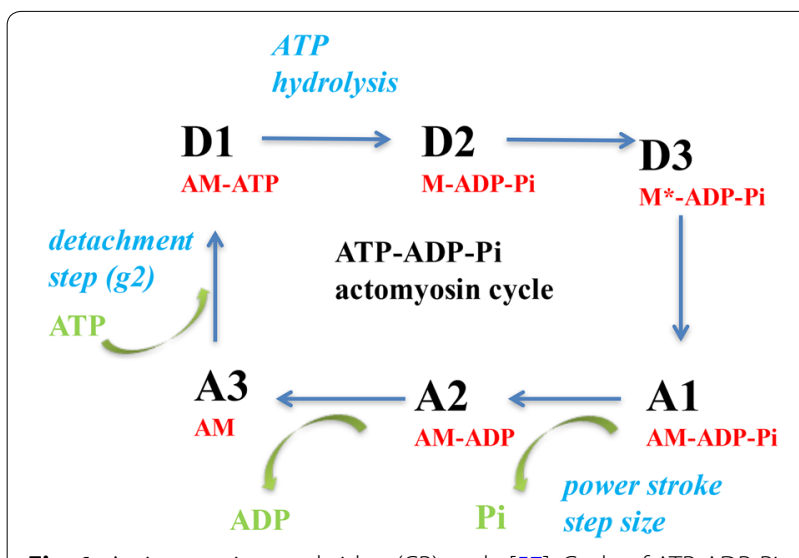

Fig. 1 Actin-myosin crossbridge (CB) cycle [57]. Cycle of ATP-ADP-Pi actin-myosin interaction. The CB cycle is composed of six successive conformational steps, i.e. three detached steps (D1, D2, and D3) and three attached steps (A1, A2, and A3). Transition A3 $\rightarrow$ D1 is the ATP binding step that induces $C B$ detachment after ATP binding to the actin (A)-myosin (M) complex (AM). The rate constant for detachment is $g_{2}: A M \rightarrow A+M$. Transition D1 $\rightarrow$ D2 is the ATP hydrolysis: $\mathrm{M}+\mathrm{ATP} \rightarrow \mathrm{M}$-ADP-Pi. Transition D2 $\rightarrow$ D3 is M-ADP-Pi $\rightarrow \mathrm{M}^{*}$-ADP-Pi. D3 is the step with the highest probability. Transition D3 $\rightarrow$ A1 is the attachment state: the myosin head ( $\mathrm{M}^{*}$-ADP-Pi) binds to $A$ and the rate constant for attachment is $\mathrm{f}_{1}: \mathrm{M}-\mathrm{ADP}-\mathrm{Pi}+\mathrm{A} \rightarrow \mathrm{AM}-\mathrm{ADP}-\mathrm{Pi}$. Transition $\mathrm{A} 1 \rightarrow \mathrm{A} 2$ is the power stroke which is triggered by the Pi release: $\mathrm{AM}-\mathrm{ADP}-\mathrm{Pi} \rightarrow \mathrm{AM}-\mathrm{ADP}+\mathrm{Pi}$. The power stroke is characterized by the generation of a unitary $C B$ force ( $\cong$ picoN) and an elementary $C B$ step $(\cong n m)$. Transition $A 2 \rightarrow A 3$ is the release of $A D P: A M-A D P \rightarrow A M+A D P$
Table 1 Comparative molecular properties of non-muscle myosin (NMII) and muscle myosin (MII)

\begin{tabular}{lccccc}
\hline & Placenta & Trachea & Soleus & EDL & Heart \\
\hline$\pi$ & $2.1(0.3)$ & $1.9(0.1)$ & $2.3(0.1)$ & $2.1(0.1)$ & $1.6(0.1)$ \\
$\mathrm{f}_{1}$ & $0.07(0.05)$ & $8.9(2.4)$ & $38(11)$ & $242(54)$ & $306(89)$ \\
$g_{2}$ & $0.33(0.24)$ & $33.5(8.4)$ & $328(99)$ & $1162(199)$ & $730(15)$ \\
ATPase activity & $4.8(0.1)$ & $2.9(1.1)$ & $5(2)$ & $50(22)$ & $283(177)$ \\
\hline
\end{tabular}

Four main parameters of crossbridge (CB) myosin molecular motors are presented. CB unitary force $(\pi ;$ in $\mathrm{pN})$; constant of $\mathrm{CB}$ attachment $\left(\mathrm{f}_{1} ;\right.$ in $\left.\mathrm{s}^{-1}\right)$; constant of $\mathrm{CB}$ detachment $\left(\mathrm{g}_{2}\right.$; in $\mathrm{s}^{-1}$ ); maximum ATPase activity (in $\mathrm{nM} \mathrm{g}^{-1} \mathrm{~s}^{-1}$ ). Values \pm SD were determined in human placenta [40], and in rat trachea, soleus, EDL and heart [50]. CB kinetics were dramatically low in non-muscle placental myofibroblasts compared with values reported in myocytes of trachea, soleus, EDL and heart. Only, CB unitary force was of same order of magnitude in both myofibroblasts and muscle cells

velocity is explained by the low constant of detachment [45, 47]. From a thermodynamic standpoint, force and flow, and the rate of entropy production, are particularly low compared to that observed in striated muscles [48].

In myofibroblasts from human placenta, the mechanical behavior of the actin-myosin apparatus is similar to that of smooth and striated muscles. The contraction phase is enhanced by either an electric field or addition of $\mathrm{KCl}$. The relaxation is increased by either 2,3-butanedione monoxime (BDM), an inhibitor of NMMII, or isosorbide dinitrate (ISDN), a NO donor [46].

In addition to the ability of myofibroblasts to contract and relax like myocytes in muscles, they share other fundamental properties, namely with respect to the Frank Starling phenomenon and the A.V. Hill hyperbolic relationship.

The Frank Starling phenomenon [49] is based on the link between the initial length of myocardial fibers and the force generated by contraction. There is a predictable association between the length between sarcomeres and the tension of the muscle fibers. There is a particular length between sarcomeres at which the tension in muscle fibers is greatest, leading to the greatest contraction force. The Franck Starling phenomenon is the observation that ventricular output increases as preload (enddiastolic pressure) increases [50, 51].

The left ventricular performance curves relate preload, measured as the left ventricular end-diastolic volume or pressure, to cardiac performance, measured as ventricular stroke volume or cardiac output. On the curve of a normally functioning heart, cardiac performance increases continuously as preload increases. During states of increased left ventricular contractility, there is a greater cardiac performance for a given preload. This is represented graphically as an upward shift of the normal curve. Conversely, during states of decreased left ventricular contractility associated with systolic heart failure, 
there is less cardiac performance for a given preload as compared to the normal curve. This is represented by a downward shift of the normal curve. Decreased contractility can also result from a loss of myocardium, as is also observed with myocardial infarction, $\beta$-blockers (acutely), non-dihydropyridine $\mathrm{Ca}^{2+}$ channel blockers, and dilated cardiomyopathy [52].

Changes in afterload, which is the resistance force that the ventricle must overcome to empty contents at the beginning of systole, will also shift the Frank-Starling curve. A decrease in afterload will cause an upward shift of the ventricular performance curve in a similar fashion to an increase in inotropy. Conversely, an increase in afterload will cause a downward shift of the curve in a similar fashion to a decrease in inotropy.

An increase in catecholamines, such as norepinephrine, during exercise will result in an upward shift of the Frank-Starling curve. Catecholamines achieve this increase by binding to a myocyte $\beta 1$-adrenergic receptor, a g-protein coupled receptor, ultimately resulting in an increased $\mathrm{Ca}^{2+}$ channel release from the sarcoplasmic reticulum which enhances the force of contraction [53].

The Frank-Starling mechanism plays a role in the compensation of systolic heart failure, buffering the fall in cardiac output to help preserve sufficient blood pressure to perfuse the vital organs. Heart failure caused by the impaired contractile function of the left ventricle causes a downward shift of the left ventricular performance curve. At any given preload, the stroke volume will be decreased with respect to normal. This reduced stroke volume leads to incomplete left ventricular emptying. Consequently, the volume of blood that accumulates in the left ventricle during diastole is greater than normal. The amplified residual volume increases the stretch of the myocardial fibers and induces a greater stroke volume with the next contraction, via the Frank-Starling mechanism. This allows for better emptying of the enlarged left ventricle and preserves cardiac output [54].

This phenomenon expresses the fact that the force developed by striated and smooth muscles depends on their initial length, which in turn depends on their preload. The longer the initial length (or the greater the preload), the greater the active tension (AT) (the active tension is the difference between total tension (TT) and preload or resting tension $(\mathrm{RT})(\mathrm{AT}=\mathrm{TT}-\mathrm{RT})$.

This phenomenon has been reported in the human placenta. Thus, modifications in the volume of the intervillous chamber modify the length of the placental stem villi. Through the Frank Starling phenomenon, contraction of myofibroblasts in placental stem villi modulates the distal resistances of the umbilical artery [46].

Secondly, myofibroblastic tissues present the hyperbolic relationship of A.V. Hill, between the maximum shortening velocity and the level of isotonic tension [55]. This mechanical property is fundamental because it allows the formalism of A. Huxley to be applied to this type of contractile tissue [56].

Huxley's equations [56] describe the behavior of crossbridge molecular motors from a phenomenological point of view in both contractile muscle and non-muscle tissues. The considerable number of cross-bridges involved in muscle and non-muscle contractile systems provides the necessary grounds for using statistical mechanics. The probabilities of several elementary steps in the actin-myosin cycle in contractile structures can thus be calculated. The combination of statistical mechanics [57] with Huxley's formalism [56] makes it possible to calculate numerous thermodynamic parameters of the system under study.

The Huxley formalism states that the curvature (G) of the hyperbola is related to the thermodynamic properties of the muscular system (the tension-velocity relationship of the contractile structures). Moreover, it is important to know the asymptotes and the curvature $G$ of the hyperbolic relationship that must be introduced into the Huxley equations. These equations are fundamental because they allow us to calculate:

- The number of CBs per unit volume of contractile tissue;

- The average unitary force of an actin-myosin interaction.

The attachment constant (fl) and detachment constants (g1 and g2) of actin from myosin CBs:

- The molar concentration of NMMII.

- The catalytic constant (kcat), which is the inverse of the duration of an actin-myosin cycle.

- The maximum ATPase activity of NMMII which is the product of kcat and the molar concentration of NMMII.

- The efficiency of the actin-myosin interaction.

In addition, Huxley's formalism leads to the calculation of the probability of the different attachment and detachment steps that the NMMII molecule undergoes during the cycle.

In our laboratory, we have developed the formalism of statistical mechanics using the grand canonical ensemble for the calculation of many thermodynamic factors, including the statistical entropy characterizing the dispersion of energy, internal energy, chemical affinity, the thermodynamic flow (TFL), the thermodynamic force (TFO) and the rate of entropy production (diS/dt) which is the product of TFL and TFO [58]. Open living 
contractile systems exchange energy and matter with the environment. In statistical mechanics, the canonical complex can be applied to complex open systems such as contractile muscle tissues. Combining statistical mechanics and the A. Huxley formalism provides a powerful tool to show the link between the chemo-mechanical properties of molecular motors $\mathrm{CB}$ and thermodynamic characteristics. This has led us to observe that striated and smooth muscles behave near equilibrium. This means that the chemical affinity is $\ll R T$ (R: gas constant, T: Kelvin temperature). Moreover, open contractile systems behave in a linear regime. This means that TFL varies linearly with TFO. In the linear regime, in which the phenomenological Onsager laws are observed [59, 60], an open system can approach a linear regime [58]. Thus, the entropy production rate $\mathrm{diS} / \mathrm{dt}$ can achieve a minimum level. This characterizes the stability criterion of a stationary regime. The irreversibility of chemical processes can be quantified by diS/dt. First, we determine the CB molecular properties and the probability of the different steps of the CB cycle by using the A.F. Huxley equations. Secondly, we can apply statistical mechanics to various muscles and establish that muscles behave near equilibrium and in a stationary linear regime $[57,59]$.

Besides muscular systems, other tissues also present contractile behavior. In a similar manner to that observed in muscle tissues, placental stem villi can contract after potassium chloride stimulation or after application of an electric field $[61,62]$. We have found that the Frank-Starling phenomenon is also present in stem villi of human placenta [46]. The ultrastructure of human placental stem villi seems to be relatively highly organized and this suggests a possible sliding of actin filaments along myosin filaments as reported in both striated and smooth muscles. The hyperbolic tension-velocity relationship is also observed in human placental stem villi [45]. This makes it possible to determine their molecular characteristics and thermodynamic properties [48]. The fundamental difference between the muscles and placenta is the dramatically low shortening velocity of the placenta compared to that of muscles. This means that placental stem villi develop a very low tension compared to that of muscles. In addition, the kinetics of NMMIIA and the NMMIIA maximum ATPase activity are much lower in human placenta than those observed in muscles [57]. Importantly, the unitary forces generated by one $\mathrm{CB}$ interaction and the thermodynamic CB efficiency are of the same order of magnitude in both muscles and non-contractile stem villi of the placenta.

We have recently shown that mesenchymal stem cells (MSCs) from human bone marrow collected after a femoral neck fracture present the same mechanical properties as those of human placental stem villi when
MSCs are included in collagen scaffolds in the presence of human platelet lysate (HPL) TGF- $\beta$ [63]. Under these conditions, MSCs differentiate into myofibroblasts. The TGF- $\beta$ induced canonical $\mathrm{WNT} / \beta$-catenin pathway increases mesenchymal stem cell (MSC) differentiation and fibroblast differentiation into myofibroblasts.

Myofibroblasts play a key role in tissue repair processes such as scarring of the skin. Canonical WNT pathways and TGF- $\beta$ promote tissue fibrosis in the heart, lungs, liver and kidneys. Finally, myofibroblasts also play a key role in several cancers [64].

Within myofibroblasts, four systems play an important key role in the initiation of the fibrotic process. These systems are PPAR $\gamma$, canonical WNT/ $\beta$-catenin signaling, TGF- $\beta$ and the Hippo pathway. These pathways operate in the pathogenesis of fibrotic processes. The pathways share the molecular mechanisms regulating the cytosolic/nuclear transfer of their transcriptional activators.

\section{PPARY}

PPAR $\gamma$ is a pleiotropic transcription factor that belongs to the superfamily of nuclear hormone receptors [65]. PPAR $\gamma$ heterodimerizes with the retinoid $X$ receptor to bind PPAR response elements (PPRE) [66]. PPARy is stimulated by ligands, which couple coactivators (p300/CBP and P160). PPARy is observed in many cells including adipose tissue, muscles, brain and cells of the immunity system. PPAR $\gamma$ stimulates the expression of numerous target genes and thus, regulates glucose homeostasis, insulin sensitivity, lipid metabolism, the immune response and inflammation [67]. PPAR $\gamma$ is also present in fibroblasts [68]. Two isoforms of PPAR $\gamma$ have also been observed. PPAR $\gamma 1$ is expressed in macrophages, epithelial cells, endothelial cells and vascular smooth muscle cells, while PPAR 2 is observed in adipose tissue, where it regulates the adipogenesis process.

PPAR $\gamma$ is stimulated by natural agents such as prostaglandin J215d (15d-PGJ2), lysophosphatidic acid and nitrolinoleic acid. PPAR $\gamma$ is stimulated by synthetic ligands, such as thiazolidinediones (TZDs) and acid derivatives, including triterpenoids oleanic (2-cyano3,12-dioxoolean-1,9-dien-28-oic acid (CDDO)). TZDs enhance insulin sensitivity in several tissues and stimulate glucose tolerance and insulin sensitivity in patients with type 2 diabetes [69]. TZDs operate on the initiators of the glucose transporter (GLUT-2) and glucokinase (GK). Moreover, PPAR $\gamma$ participates in the regulation of connective tissue, activation of mesenchymal cells, differentiation, and cell survival by linking with the metabolism and fibrogenesis [14]. PPAR $\gamma$ abnormalities are present in many pathophysiological conditions, including obesity, cancer, diabetes, atherosclerosis and multiple sclerosis. Many TZDs have been used in the treatment of 
diabetes mellitus. Nevertheless, side effects induced by TZDs have also been reported [70]. Benefits enhanced by TZDs are mitigated by the possibility for water retention, congestive heart failure, weight gain, bone loss and liver kidney diseases. It therefore seems to be of the utmost importance to initiate the development of new molecules to diminish the negative effects induced by TZD use. PPARy also plays a major role in controlling cardiovascular rhythms by monitoring changes in the circadian rhythms of blood pressure and heart rate via Bmal1 [71].

PPARY has a vital role in the fibrosis process and in cutaneous lesions. When the skin is disturbed due to injury, resident fibroblasts are submitted to mechanical stress. This stress, coupled with a TGF- $\beta 1$ release from immune cells and platelets at the site of the wound, leads to the migration of dermal fibroblasts from normal surrounding skin near the site of injury [72]. Thus, fibroblasts differentiate into myofibroblasts. PPAR $\gamma$ play a major role in decreasing the fibrotic process by antagonizing TGF- $\beta 1$. PPAR $\gamma$ agonists decrease the deposition of TGF- $\beta$ induced collagen and myofibroblast differentiation [73]. Excessive scarring and/or chronic wounds may constitute a major problem during tissue injury. The discovery of new drugs to minimize fibro-proliferative processes is of considerable significance. PPAR $\gamma$ could be useful in the prevention of excessive scarring. It is important now to clarify whether the PPAR $\gamma$ agonists induce positive effects on the repair of skin tissue in humans.

\section{PPARY modulators}

PPARY expression is decreased by many cytokines, chemokines, and intracellular pathways decrease, such as TFG- $\beta 1$, canonical WNT/ $\beta$-catenin pathway, TNF$\alpha$, Interleukin (HE)-1 $\beta$, IFN- $\gamma$, HE-13, connective tissue growth factor (CTGF), leptin and lysophosphatidic acid (LPA) [74, 75]. The transcription factor COUP II is a canonical WNT target which reduces PPARy. Hypoxia reduces PPAR $\gamma$ expression [76]. Other molecules stimulate PPAR $\gamma$ expression, such as adiponectin, TZDs, L-carnitine, statins, eplerenone, and irbesartan [77]. Adiponectin helps stimulate PPAR 2 expression and reduce activation and production of IL-6 NF-kappaB induced by LPS in adipocytes [78]. Other transcription factors modulate PPARY in a positive manner, such as C/EBP, ELF proteins, and NF-E2-related factor 2 (Nrf2), the receiver of the bile acid receptor farnesoid X (FXR), which binds to the canonical WNT pathway [79].

\section{The canonical WNT/ $\beta$-catenin pathway}

The canonical WNT/ $\beta$-catenin pathway has a major role in metabolism, embryonic development, cell fate, and the epithelial-mesenchymal transition (EMT) [80]. Stimulation of canonical WNT signaling leads to an increase in the nuclear and cytosolic levels of $\beta$-catenin (Fig. 2). In the "on" state, canonical WNT ligands interact with both the canonical WNT receptor frizzled (FZL) and the related protein 5/6 LDL receptor (LRP5/6), FDZ complex, and with disheveled (DSH). This dysregulates the destruction complex to prevent $\beta$-catenin degradation in the proteasome. The destruction complex is composed of a suppressor, adenomatous polyposis coli tumor

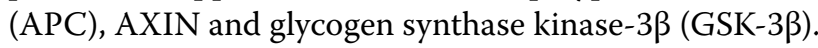
$\beta$-catenin translocates to the nucleus to bind the T cell/ lymphoid amplifier (TCF/LEF) transcription factors. This phenomenon stimulates several $\beta$-catenin target genes (c-Myc, Cyclin D, Cox 2, AXIN, PDK, MTC-1) [81, 82]. In the absence of WNT ligands, the destruction complex phosphorylates $\beta$-catenin, which is destroyed in the proteasome. Dysregulated canonical WNT signaling has been observed in numerous diseases such as cancers $[4,83-85]$. Stimulation of the WNT/ $\beta$-catenin has been observed in the liver, skin, lungs, kidneys and heart in fibrotic processes $[86,87]$.

\section{Interplay between the WNT pathway and PPARY}

Canonical WNT signaling is negatively regulated by PPARY ligands $[84,88,89]$. Stimulation of the canonical WNT/- $\beta$-catenin pathway is a major phenomenon involved in the fibrotic pathogenesis [90]. TZDs stimulate DKK1, which is an inhibitor of the canonical WNT pathway (Fig. 2), and block the differentiation of fibroblasts [91]. GW11929, a non-TZD PPARY agonist, decreases the transcription of $\beta$-catenin [92]. The inhibitory role induced by canonical WNT signaling on PPARY has been observed to be the phenomenon that leads to the anti-adipogenic effects [93]. During osteoblastogenesis, WNT signaling is directly activated by the inhibition of both PPAR $\gamma$ and the enhancer-binding protein CCAAT/ [94]. Thus, stimulation of $\mathrm{WNT} / \beta$-catenin signaling and downregulation of GSK-3 $\beta$ activity leads to the activation of fibroblast differentiation and fibrotic processes [95].

In addition, downregulation of PPAR $\gamma$ enhanced by WNT ligands can be carried by non-canonical pathways [93]. The non-canonical WNT pathway through CaMKIITAK1-NLK-TAB 2 inhibits the transactivation of PPAR $\gamma$.

\section{TGF- $\beta 1$}

TGF- $\beta$ are composed of three similar structural proteins, namely TGF- $\beta 1$, TGF- $\beta 2$ and TGF- $\beta 3$. TGF- $\beta$ receptors are transmembrane proteins and include the type I receptor (T $\beta R I)$ and type II receptor (T $\beta R I I)$ (Fig. 2). TGF- $\beta 1$ can bind T $\beta R 2$ but not T $\beta R 1$. TGF$\beta 1$ is secreted and deposited in ECM as a large latent complex, comprising a latent TGF- $\beta 1$ binding protein bound to a small latent complex. Integrins $\alpha_{\mathrm{v}} \beta 5$ and $\alpha_{\mathrm{v}} \beta 6$ stimulate TGF- $\beta 1$. In addition, TGF- $\beta 1$ stimulates 


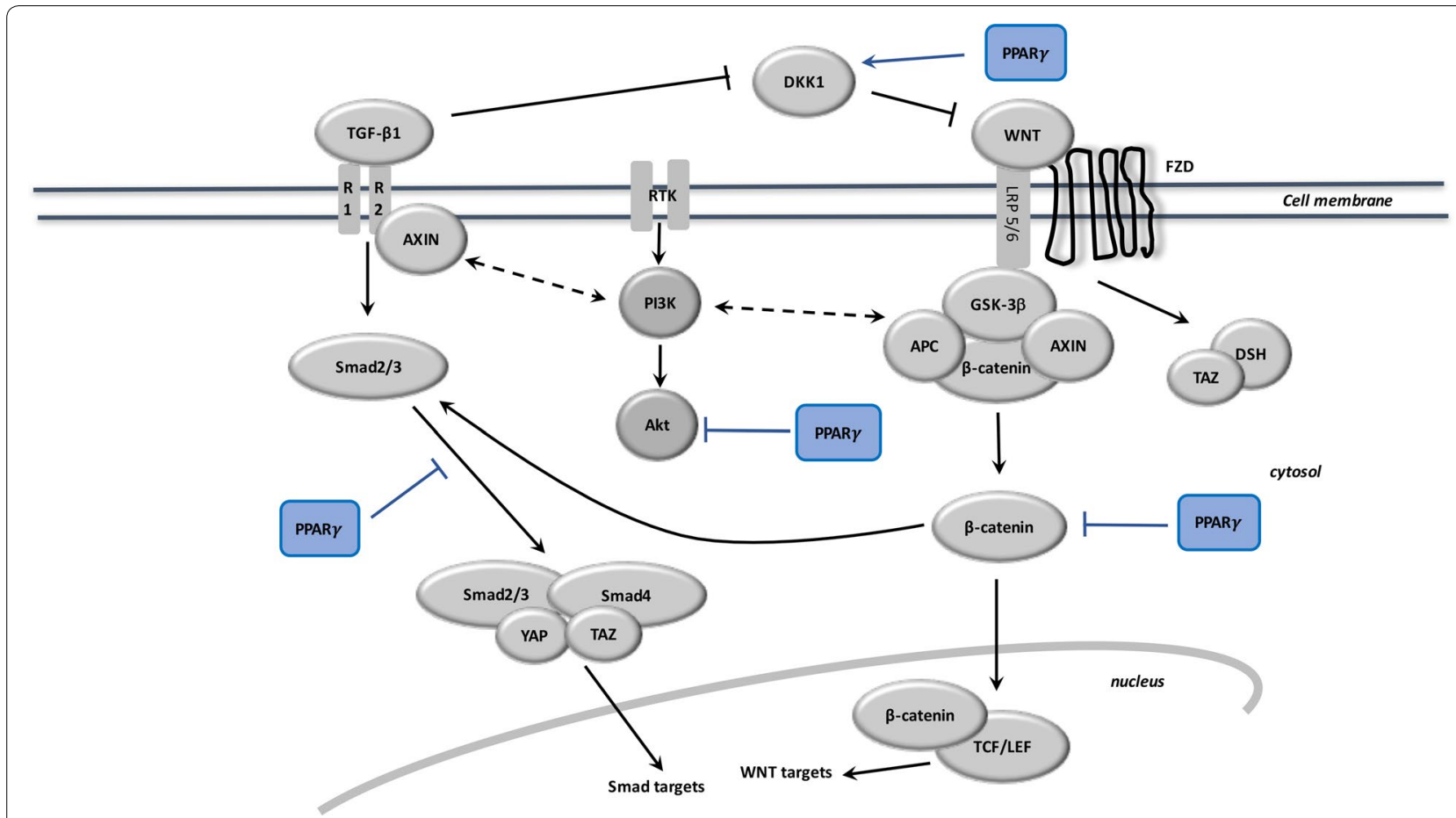

Fig. 2 TGF- $\beta 1$ effects on the balance between the canonical WNT/ $\beta$-catenin pathway and PPARy. WNT activation inhibits the $\beta$-catenin destruction complex, which results in the $\beta$-catenin accumulation in the cytosol and then its translocation to the nucleus for activating WNT target genes. Following WNT stimulation, TAZ inhibits the phosphorylation of DSH and dissociates it from the $\beta$-catenin destruction complex. The destruction complex is inhibited because YAP and TAZ dissociate from the complex. Following TGF- $\beta$ stimulation, AXIN promotes the tail-phosphorylation of Smad2/3. The activated Smad2/3-Smad4 complex associates with TAZ and YAP and then translocates to the nucleus for activation of Smad targets. TGF- $\beta 1$ induces Smad2/3 and PI3K/AKT pathway activation. PPARY inhibits $\beta$-catenin/TCF-LEF-induced activation of the WNT target genes. TGF- $\beta$ also enhances WNT signaling through inhibition of DKK1. PPARY actives DKK1 and inactivates PI3K/AKT. APC adenomatous polyposis, DKK1 Dickkopf-1, DSH disheveled, FZD frizzled, GSK-3 $\beta$ glycogen synthase kinase-33, LRP5/6 protein 5/6 connected to the low-density lipoprotein receptor, PPARy peroxisome proliferator-activated receptor gamma, TCF/LEF T cell factor/lymphoid enhancer factor, TGF transforming growth factor

Smad signaling and non-Smad signaling, including MAPK, Rho, and PI3K-AKT. TGF- $\beta 1$ stimulates PI3K/ AKT by activating focal adhesion kinase (FAK) [96, 97]. FAK is a non-receptor protein tyrosine kinase that is phosphorylated in response to integrin clustering and growth factor-mediated migration [98]. FAK is recruited to focal adhesion following integrin clustering [99], and is subsequently activated by phosphorylation at Tyr297. Activation of the phosphorylation of FAK is correlated with its increased catalytic activity $[100,101]$ and is required for the recruitment of p85, a regulatory subunit of PIEK/AKT [102]. Thus, FAK is involved in myofibroblast differentiation via TGF- $\beta 1$ [103]. FAK is involved as an upstream activator of AKT and then contributes to fibrogenesis [104, 105]. Several fibrotic disorders present an activation of the TGF- $\beta 1$ pathway. Thus, TGF- $\beta 1$ is elevated in glomerular and tubulo-interstitial diseases, in diabetes mellitus, in lungs, in the broncho-alveolar lavage of patients with SSc, and hypertrophic and restrictive cardiomyopathy [106-108].

\section{Interplay between PPARy, canonical WNT and TGF- $\boldsymbol{\beta} 1$ (Figs. 2 and 3 )}

The observed link between TGF- $\beta 1$, canonical WNT/ $\beta$ catenin and PPAR $\gamma$ has been well documented [77]. TGF- $\beta 1$ can activate canonical WNT signaling, and can decrease PPAR $\gamma$ expression. In contrast, PPAR $\gamma$ decreases the TGF- $\beta 1 / \mathrm{WNT} / \beta$-catenin pathway. PPAR $\gamma$ ligands lead to a decrease in TGF- $\beta 1$ through PI3K/AKT signaling [109]. TGF- $\beta 1$ is a major controller of fibrosis and an interesting target in fibrosis [110]. TGF- $\beta 1$ leads to fibroblast differentiation into myofibroblasts in the human lung. The fibrosis process is decreased through the inhibition of TGF- $\beta 1$ by means of PPAR $\gamma$ agonists [111]. PPAR $\gamma$ induces protection against excessive fibrogenesis [112]. In the eye, PPAR ligands (15-deoxy-prostaglandin J2 delta 12,14, troglitazone, rosiglitazone) may remove corneal myofibroblasts [113].

The opposing interplay between PPAR $\gamma$ and TGF$\beta 1$ would in part support the fibrosis process. TGF- $\beta 1$ activation promotes the differentiation of fibroblasts into myofibroblasts and negatively regulates PPARY 


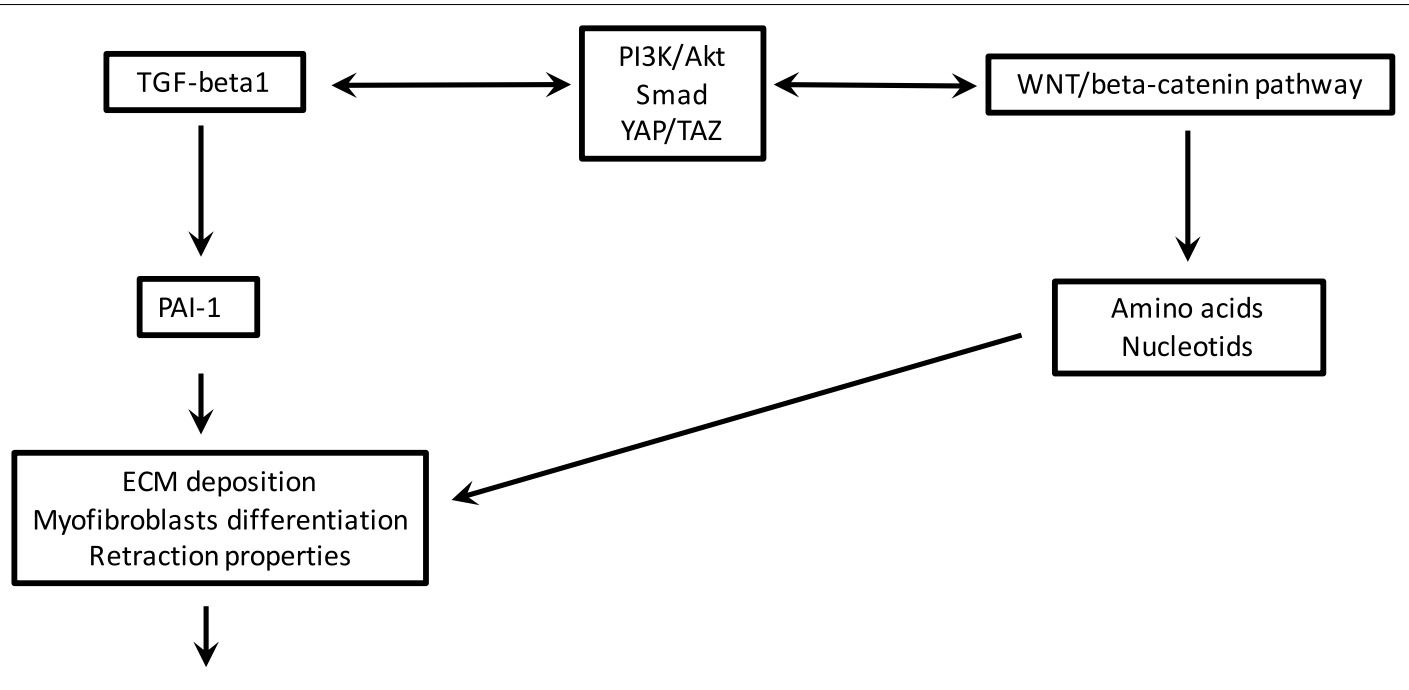

Fibrosis

Fig. 3 Schematic representation of the fibrosis process with the interaction between TGF- $\beta 1$ and the canonical WNT/ $\beta$-catenin pathway

expression. TGF- $\beta 1$ reduces PPAR $\gamma$ expression in both fibroblasts [114] and hepatic stellate cells [115]. In contrast, PPAR $\gamma$ agonists directly disrupt the TGF- $\beta$ pathway and its synthesis [116]. PPAR ligands (15d-PG)2 and troglitazone) inhibit the expression and synthesis of collagen in fibroblasts enhanced by TGF- $\beta 1[116,117]$. Troglitazone, 15d-PGJ 2 and CDDO prevent $\alpha$-SMA expression [118]. PPAR $\gamma$ agonists decrease TGF- $\beta 1$-induced CTGF expression [119]. In pulmonary fibrosis induced by bleomycin, the diminution of canonical WNT/TGF- $\beta 1$ signaling decreases LRP5 and reduces fibrosis [120]. TGF- $\beta 1$ also enhances WNT signaling by inhibiting Dickkopf-1 (DKK1) [121]. Even if DDK1 inhibits TGF- $\beta$-induced fibrosis, the decrease in DKK1 activity leads to the stability and nuclear accumulation of $\beta$-catenin in epithelial cells and fibroblasts, which encourages the fibrotic process.

\section{The Smad pathway}

The Smad pathway helps us to better understand the association between TGF- $\beta 1$, the WNT pathway and PPARy (Fig. 2). In myofibroblasts, stimulation of the canonical Smad pathway controls the intracellular TGF$\beta 1$ pathway. TGF- $\beta 1$ binds TGF $\beta$ R2 to recruit TGF $\beta R 1$. This mechanism helps induce the formation of a heterotetramer and phosphorylation of Smad 2 and Smad 3, which then binds Smad 4 (Fig. 2). This activates the recruitment of coactivators, including p300 histone acetyltransferase, and targets gene transcription [122].

Non-Smad pathways exist as p38 MAP kinase and JNK, TGF- $\beta$ stimulated kinase (TAK1), the focal adhesion kinase and PI3K-AKT [120]. Furthermore, CTGF, the platelet-derived growth factor (PDGF), IL-4, IL-6, IL-8 and IL-13 interact with TGF- $\beta 1$ and participate in the fibrotic process [123]. PPAR $\gamma$ ligands disrupt both Smaddependent and Smad-independent TGF- $\beta 1$ signaling. Downregulation of PPAR $\gamma$ promotes the canonical Smad signaling $2 / 3$. In humans, the PPAR $\gamma$ promoter has two Smad connecting elements [115].

\section{Interplay between Smad/TGF $\beta 1$ and canonical WNT/PPARY pathways in fibrosis}

Regulation of the homeostasis of connective tissue represents a recently discovered role of PPAR $\gamma$, especially in tissue repair and fibrotic processes. In general, an opposing interplay has been observed between PPARY expression and the fibrotic process. In human fibrosis diseases, PPAR $\gamma$ expression is decreased, as in lung, scarring, alopecia [124], liver [125], and kidney [126] diseases. In numerous fibrotic processes, decreased PPAR $\gamma$ expression and/or activity precedes the fibrotic process, suggesting a causal role for fibrosis [5]. In mice with systemic sclerosis, PPAR $\gamma$ expression is reduced in the skin tissue and rosiglitazone abrogates bleomycin-induced scleroderma and blocks responses by a PPAR $\gamma$ profibrotic mechanism [116]. PPAR $\gamma$-deficient fibroblasts show increased TGF- $\beta 1$, collagen type 1 , and $\alpha$-SMA [127].

The Smad pathway could explain the anti-fibrotic role of PPAR $\gamma$ ligands. PPAR $\gamma$, through the inhibition of TGF- $\beta$ signaling, can help control fibrosis processes. Thus, overexpression of PPAR $\gamma$ participates in the regulation of fibrosis development in skin, lung, pancreas, heart 
and liver [114]. PPAR $\gamma$ agonists inhibit TGF- $\beta 1 / \mathrm{Smad} 3$ signaling in human hepatic stellate cells [128]. Activated PPAR $\gamma$ ligands suppress the production of collagen in accordance with Smad targeting of the transcription coactivator p300 [117]. Triterpenoid improves fibrosis [118]. In fibroblasts, CDDO can prevent TGF $\beta 1$-induced fibrotic processes by removing the Smad transcription and the downregulation of the AKT pathway [118]. Troglitazone, ciglitazone and 15d-PGJ 2 results in an overexpression of the hepatocyte growth factor (HGF), which leads to activation of the TG-interaction factor (TGIF), a co-Smad transcriptional repressor, and prevents the TGF- $\beta 1$-induced fibrotic process [129]. The differentiation of human peripheral blood fibrocytes is mediated by TGF- $\beta 1$ and PPAR $\gamma[130]$. Then, troglitazone inhibits the TGF- $\beta 1$-induced SAPK/JNK signaling that reduces the Smad2 activity and modifies myofibroblast differentiation. PPAR $\gamma$ ligands diminish TGF- $\beta$-mediated Erg1 signaling [131].

PPARY can exert a negative control on the synthesis of the collagen-induced profibrotic signal and blunting fibrosis in several pathological conditions [5, 6]. Moreover, in lung and cultured skin fibroblasts, hepatic stellate cells and mesangial cells, PPARy ligands (15d-PG)2 and rosiglitazone) decrease the differentiation of fibroblasts into myofibroblast, the synthesis of collagen, fibronectin and TGF- $\beta 1[125,132]$. PPAR $\gamma$ ligands can stop the epithelial-mesenchymal transition of alveoar epithelial cells induced by TGF- $\beta 1$ [133].

In mice, adiponectin prevents fibrosis in the liver [134]. In numerous animal models of fibrosis, PPAR ligands decrease fibrosis in numerous organs, including heart [135], lung [136], liver [137] and kidney [138]. PPAR $\gamma$ 15d-PGJ2 agonist and rosiglitazone decrease pulmonary fibrosis induced by systemic sclerosis [139].

PPAR $\gamma$-induced tensin homologue, PTEN, induces an anti-fibrotic effect in pulmonary fibrosis and SSc [140]. PTEN inhibits the production of collagen and myofibroblast differentiation [141]. PPAR $\gamma$ suppresses TGF- $\beta 1$ enhanced EMT in alveolar epithelial cells and metastasis, without blocking the Smad pathway [142]. In PPARy deficient mice, phosphorylation of Smad3 is increased and $\alpha$-SMA and type 1 collagen expression is stimulated [127]. WNT3a promotes myofibroblast differentiation through the upregulation of TGF- $\beta 1$. This occurs in a Smad2 $\beta$-catenin dependent manner [143]. In addition, it has been observed that aerobic glycolysis is enhanced by TGF- $\beta 1$ activation [144].

\section{Non-Smad-dependent signaling and fibrosis}

PPAR $\gamma$ agonists may prevent TGF- $\beta 1$-induced fibrosis, regardless of the Smad pathway [73, 116]. Thus, rosiglitazone does not inhibit Smad2 phosphorylation.
In lung fibroblasts, myofibroblastic dedifferentiation by PTEN diminishes collagen expression and $\alpha$-SMA [140]. PTEN downregulates the PI3-OH kinase, (PI3K)AKT. PI3K leads to the formation of phosphatidylinositol 3,4,5-triphosphate (PIP3) from PIP2. AKT is stimulated by PIP3. PTEN is a PIP3 phosphatase that acts in a way that opposes the role of PIK3. PPAR $\gamma$ ligands suppress TGF- $\beta 1$ and target the PI3K/AKT [109], which induces the differentiation of myofibroblasts.

\section{The Hippo pathway}

Yes-associated protein 1/transcription coactivator and PDZ-binding motif (YAP/TAZ) are transcription coactivators of the Hippo kinase complex [145]. Hippo signaling controls organ size and the regeneration and self-renewal of cells. Hippo signaling consists of numerous components including serine/threonine protein kinases (MST1/2), MOB kinase activator 1 (MOB1), Salvador (SAV) and the serine/threonine protein kinase(LATS1/2). When the kinase Hippo is in the "on" state, YAP and TAZ are phosphorylated and lead to a phosphodegron. YAP and TAZ may be sequestered in the cytosol or degraded by $\beta$-TrCP proteins. Activated Hippo signaling induces phosphorylation of YAP and leads to a reduction in the $\beta$-catenin level.

During the fibrosis process, F-actin polymerization downregulates MST1/2 activity, which inactivates the Hippo complex. Then, YAP and TAZ are released and translocated to the nucleus where they bind with several transcription factors, including transcription factor Runt (RunX) and the TEA domain family member (TAED), to activate gene transcription.

YAP and TAZ are involved in the activation of myofibroblasts and the initiation of fibrosis. In biopsies of idiopathic pulmonary fibrosis, both YAP and TAZ levels are high, and induce activation of fibroblasts and then fibrosis. In lung fibroblasts and mouse liver, knockdown YAP and TAZ reduce procollagen, $\alpha$-SMA, and the inhibitor of plasminogen activator 1 , which have all been linked with myofibroblast differentiation [146].

\section{Interaction of TGF- $\beta$ pathways, WNT, Smad and the Hippo pathway in fibrosis (Fig. 4)}

An intricate interplay exists in myofibroblast differentiation. During the healing of skin wounds in mice, observations have shown that both YAP and TAZ are increased. TGF- $\beta 1$ is stimulated in skin wound healing. This suggests a link between YAP and TAZ stimulation and TGF$\beta 1$ activation [147]. YAP and TAZ also control the activity and expression of the TGF- $\beta 1$ component pathway including Smad-2. WNT3a induces myofibroblast differentiation by improving TGF- $\beta 1$ through phosphorylation of Smad2 in a dependent $\beta$-catenin manner [143]. 


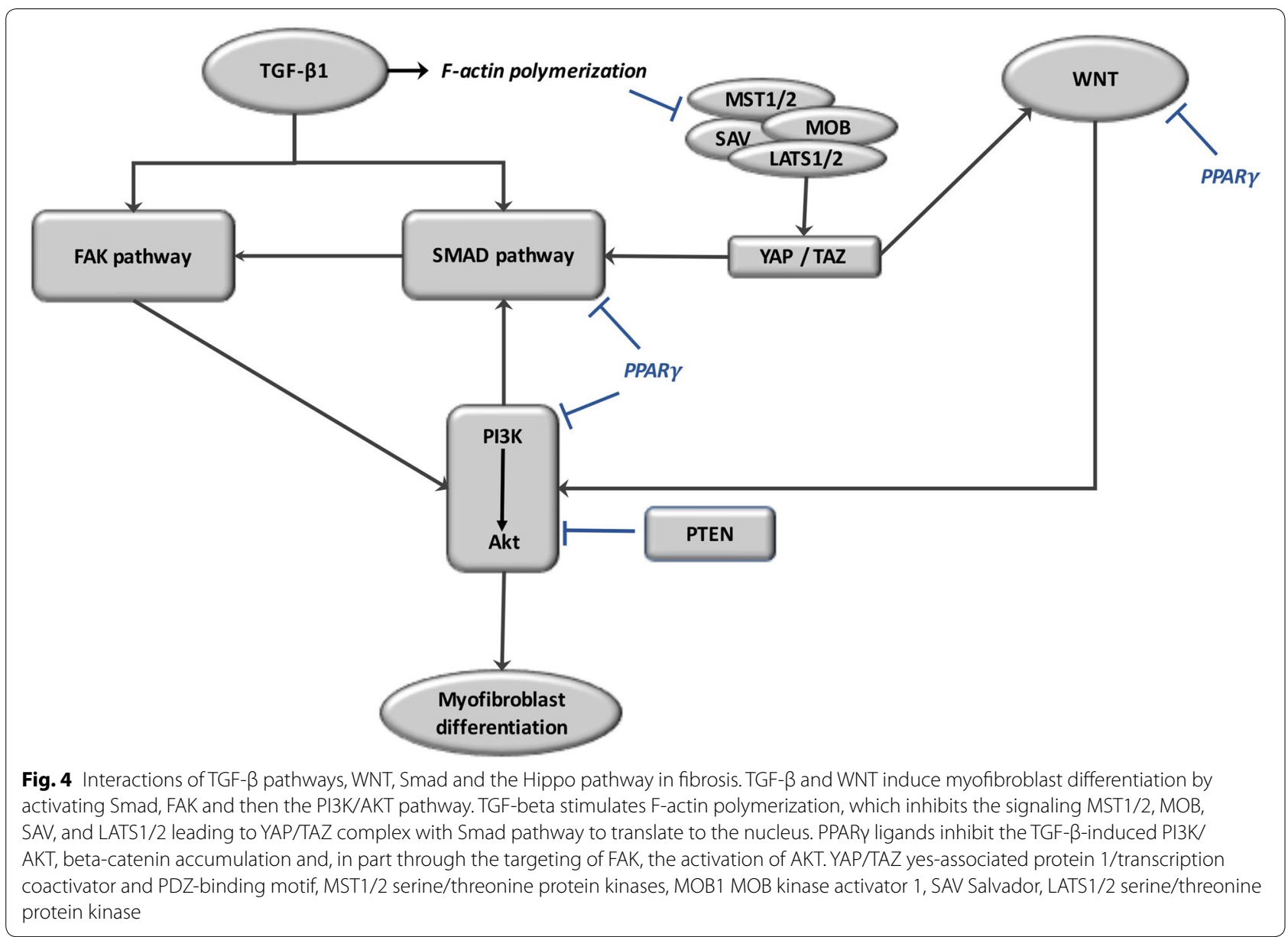

An interplay has also been observed between the YAP/ TAZ pathway and TGF- $\beta$. In epithelial cells, TAZ interacts with Smad2/Smad3 [148]. TAZ binds with Smad2/3 to increase the transfer of Smad2/3 in the nucleus and thus the transcription of PAI-1 and Smad7 target genes. Furthermore, in mesothelioma cells, YAP binds with Smad3 [149]. In the cytosol, TAZ is linked with canonical WNT signaling by an interaction of TAZ- $\beta$-catenin [150]. During the "on"-state of WNT signaling, the release of $\beta$-catenin from the destruction complex alters TAZ degradation, leading to the cytosolic accumulation of both $\beta$-catenin and TAZ. This impact of TAZ on the WNT pathway is independent of its function as a mediator of Hippo signaling. In the "off"-state of the WNT pathway, cytosolic YAP/TAZ specifically binds with AXIN [151].

\section{New molecular insights into fibrosis}

Several potential cellular sources of extracellular matrixproducing cells can promote fibrosis [152]. Mesothelial cells derive from the embryonic mesoderm cell layer and play a protective role in the internal organs of the body by producing a lubricating fluid that helps protect the body against infection. TGF- $\beta$ has been shown to induce a reformation of the "mesothelial-to-mesenchymal transition" in differentiated human mesothelial cells, via a positive $\alpha$-SMA loop [153]. Endothelial cells can differentiate into mesenchymal cells, by an "endothelial-to-mesenchymaltransition", and then contribute to fibrosis [154]. Vascular smooth muscle cells typically express $\alpha$-SMA and induce collage type I production via autocrine activation of TGF- $\beta 1$ and involvement of mitogen-activated protein kinase pathways [155]. TGF- $\beta$ is considered as one of the common master switches for induction of the fibrotic program during chronic phases of inflammatory diseases in many organs. Other important soluble pro-fibrogenic mediators include the connective tissue growth factor (CTGF) and members of the platelet-derived growth factor (PDGF) family of growth factors. While CTGF is thought to bind with TGF- $\beta$ and enhance its binding to membrane-bound receptors, members of the PDGF family are potent mitogens and chemoattractant for fibrogenic cells in most organs driving the recruitment and proliferation of these cells at sites of tissue injury [156]. In parallel, several interleukins, such as IL- 1 and IL-6, are 
critical proinflammatory contributors to the pathogenesis of fibrosis [153]. Lipid laden macrophages (i.e. foam cells) release oxidized phosphatidylcholine to induce the production of TGF- $\beta$ and then the promotion of M2 polarization of macrophages during the fibrosis process (Kubo 2018). Recent targets in fibrosis biomarker research include circulating micro-RNA (miRNA), long non-coding RNA, epigenetic changes, mitochondrial DNA or microbiome signatures in the stool [157-159]. Many new directions of research are therefore aimed at improving strategies for targeting drugs at myofibroblasts [160]. Potential targeting systems include modified albumin, hydrogel, peptide, nanoparticle, aptamer and antibody-based systems, which demonstrated promising myofibroblast targeting capacities in preclinical models [160-162].

\section{Conclusion}

Several signaling systems can exercise control over the differentiation of fibroblasts into myofibroblasts. Furthermore, myofibroblasts have a major function in cell fibrosis in several organs, such as the kidneys, heart, lungs, and liver, and in wound healing. Canonical WNT/ $\beta$ catenin signaling and PPAR $\gamma$ behave in an opposing manner, and thus participate in respectively promoting and reducing fibrosis. TGF- $\beta$ has a major role in the fibrotic process by acting on the contractile properties of myofibroblasts (Fig. 3). TGF- $\beta$ regulates the differentiation of fibroblasts into myofibroblasts and can act as a driver by upregulating the canonical WNT pathway and downregulating PPAR $\gamma$.

With respect to the human clinical approach, no treatment has yet been able to stop and regress fibrosis. Many attempts have used antagonist antibodies or small molecules that act on the TGF- $\beta$, canonical WNT, Smad and YAP/TAZ cascades. Although considerable therapeutic efficacy has been observed in animal models [163], evidence from human trials to date is insufficient. Indeed, some studies have indicated that there may be serious side effects, while other human trials have been more encouraging, especially in scleroderma [164]. in the lack of sufficient results to ensure effective control of the fibrotic process may be partly due to the complex relationship between the different signaling systems (TGF$\beta$, canonical WNT/ $\beta$-catenin, and Smad-Hippo/YAP/ TAZ), which may be partially opposed to one another. PKC- $\delta$ and angiotensin inhibitors also exhibit remarkable anti-profibrotic roles and can be used to in implementing efficient therapies in the fibrotic process [110]. In addition, PPAR $\gamma$ may interrupt the actions of profibrotic TGF- $\beta$, myofibroblast differentiation and excess collagen production.

\section{Abbreviations}

APC: adenomatous polyposis; DKK1: Dickkopf-1; DSH: disheveled; FZD: frizzled; GSK-3 3 : glycogen synthase kinase-3 3 ; LRP5/6: protein 5/6 connected to the low-density lipoprotein receptor; PPARY: peroxisome proliferator-activated receptor gamma; TCF/LEF: T cell factor/lymphoid enhancer factor; TGF: transforming growth factor; YAP/TAZ: yes-associated protein 1/transcription coactivator and PDZ-binding motif; MST1/2: serine/threonine protein kinases; MOB1: MOB kinase activator 1; SAV: Salvador; LATS1/2: serine/threonine protein kinase.

\section{Acknowledgements \\ The authors thank Mr. Brian Keogh, Ph.D., for the proofreading of the manuscript.}

\section{Authors' contributions}

$A V$ and $Y L$ have contributed equally to this review. Both authors read and approved the final manuscript.

\section{Funding}

No funding.

\section{Availability of data and materials Not applicable.}

\section{Ethics approval and consent to participate} Not applicable.

\section{Consent for publication}

$\mathrm{AV}$ and $\mathrm{YL}$ consent for publication.

\section{Competing interests}

The authors declare that they have no conmpeting interests.

\section{Author details}

1 Délégation à la Recherche Clinique (DRCI), Hôpital Foch, Suresnes, France. 2 DACTIM-MIS, Laboratoire de Mathématiques et Applications (LMA), CNRS, UMR 7348, Université de Poitiers, CHU de Poitiers, Poitiers, France. ${ }^{3}$ Centre de Recherche Clinique, Grand Hôpital de l'Est Francilien (GHEF), Meaux, France.

Received: 6 June 2019 Accepted: 30 November 2019

Published online: 09 December 2019

\section{References}

1. Gabbiani G, Ryan GB, Majne G. Presence of modified fibroblasts in granulation tissue and their possible role in wound contraction. Experientia. 1971;27:549-50.

2. Carrel A, Hartmann A. Cicatrization of wounds: I. The relation between the size of a wound and the rate of its cicatrization. J Exp Med. 1916:24:429-50.

3. Zampieri F, Coen M, Gabbiani G. The prehistory of the cytoskeleton concept. Cytoskeleton. 2014;71:464-71.

4. Vallée A, Lecarpentier Y, Guillevin R, Vallée J-N. Thermodynamics in gliomas: interactions between the canonical WNT/beta-catenin pathway and PPAR gamma. Front Physiol. 2017;8:352.

5. Vallée A, Lecarpentier Y, Vallée J-N. Thermodynamic Aspects and reprogramming cellular energy metabolism during the fibrosis process. Int J Mol Sci. 2017;18:2537.

6. Vallée A, Lecarpentier Y, Guillevin R, Vallée J-N. Interactions between TGF- $\beta 1$, canonical WNT/ $\beta$-catenin pathway and PPAR $\gamma$ in radiationinduced fibrosis. Oncotarget. 2017;8:90579-604.

7. Vallée A, Lecarpentier $Y$, Vallée J-N. Curcumin: a therapeutic strategy in cancers by inhibiting the canonical WNT/B-catenin pathway. J Exp Clin Cancer Res. 2019;38:323.

8. Vallée A, Lecarpentier Y, Vallée J-N. Targeting the Canonical WNT/Bcatenin pathway in cancer treatment using non-steroidal anti-inflammatory drugs. Cells. 2019;8:726.

9. Vallée A, Vallée J-N, Guillevin R, Lecarpentier Y. Interactions between the canonical WNT/beta-catenin pathway and PPAR gamma on neuroinflammation, demyelination, and remyelination in multiple 
sclerosis. Cell Mol Neurobiol. 2018;38(4):783-95. https://doi. org/10.1007/s10571-017-0550-9.

10. Vallée A, Lecarpentier Y, Guillevin R, Vallée J-N. Effects of cannabidiol interactions with Wnt/ $\beta$-catenin pathway and PPARY on oxidative stress and neuroinflammation in Alzheimer's disease. Acta Biochim Biophys Sin. 2017:49:853-66.

11. Vallée A, Lecarpentier Y, Guillevin R, Vallée J-N. Thermodynamics in neurodegenerative diseases: interplay between canonical WNT/betacatenin pathway-PPAR gamma, energy metabolism and circadian rhythms. Neuromol Med. 2018;20:174-204.

12. Vallée $A$, Lecarpentier $Y$, Guillevin R, Vallée J-N. Demyelination in multiple sclerosis: reprogramming energy metabolism and potential PPARy agonist treatment approaches. Int J Mol Sci. 2018:19:1212.

13. Vallée A, Lecarpentier $Y$, Vallée J-N. Hypothesis of opposite interplay between the canonical WNT/beta-catenin pathway and PPAR gamma in primary central nervous system lymphomas. Curr Issues Mol Biol. 2019;31:1-20.

14. Wei J, Bhattacharyya S, Jain M, Varga J. Regulation of matrix remodeling by peroxisome proliferator-activated receptor- $\gamma$ : a nove link between metabolism and fibrogenesis. Open Rheumatol J. 2012;6:103-15.

15. Gabbiani G, Chaponnier C, Hüttner I. Cytoplasmic filaments and gap junctions in epithelial cells and myofibroblasts during wound healing. J Cell Biol. 1978:76:561-8

16. Tomasek JJ, Gabbiani G, Hinz B, Chaponnier C, Brown RA. Myofibroblasts and mechano-regulation of connective tissue remodelling. Nat Rev Mol Cell Biol. 2002:3:349-63.

17. Serini G, Bochaton-Piallat ML, Ropraz P, Geinoz A, Borsi L, Zardi L, et al. The fibronectin domain ED-A is crucial for myofibroblastic phenotype induction by transforming growth factor-beta1. J Cell Biol. 1998;142:873-81.

18. Desmoulière A, Redard M, Darby I, Gabbiani G. Apoptosis mediates the decrease in cellularity during the transition between granulation tissue and scar. Am J Pathol. 1995;146:56-66.

19. Micallef $L$, Vedrenne $N$, Billet $F$, Coulomb B, Darby IA, Desmoulière A. The myofibroblast, multiple origins for major roles in normal and pathological tissue repair. Fibrogenesis Tissue Repair. 2012;5:S5.

20. Desmoulière A, Tuchweber B, Gabbiani G. Role of the myofibroblast differentiation during liver fibrosis. J Hepatol. 1995;22:61-4.

21. Leask A, Abraham DJ. TGF-beta signaling and the fibrotic response. FASEB J. 2004;18:816-27.

22. Hinz B. Myofibroblasts. Exp Eye Res. 2016:142:56-70.

23. Hinz B, Phan SH, Thannickal VJ, Prunotto M, Desmoulière A, Varga J, et al. Recent developments in myofibroblast biology: paradigms for connective tissue remodeling. Am J Pathol. 2012;180:1340-55.

24. Cleary PE, Minckler DS, Ryan SJ. Ultrastructure of traction retinal detachment in rhesus monkey eyes after a posterior penetrating ocular injury. Am J Ophthalmol. 1980;90:829-45.

25. Schmitt-Gräff A, Pau H, Spahr R, Piper HM, Skalli O, Gabbiani G. Appearance of alpha-smooth muscle actin in human eye lens cells of anterior capsular cataract and in cultured bovine lens-forming cells. Differ Res Biol Divers. 1990;43:115-22.

26. Moore-Morris T, Guimarães-Camboa N, Banerjee I, Zambon AC Kisseleva T, Velayoudon A, et al. Resident fibroblast lineages mediate pressure overload-induced cardiac fibrosis. J Clin Invest. 2014;124:2921-34

27. Van De Water L, Varney S, Tomasek JJ. Mechanoregulation of the myofibroblast in wound contraction, scarring, and fibrosis: opportunities for new therapeutic intervention. Adv Wound Care. 2013;2:122-41.

28. Hao H, Gabbiani G, Camenzind E, Bacchetta M, Virmani R, BochatonPiallat M-L. Phenotypic modulation of intima and media smooth muscle cells in fatal cases of coronary artery lesion. Arterioscler Thromb vasc Biol. 2006;26:326-32.

29. Friedman SL. Evolving challenges in hepatic fibrosis. Nat Rev Gastroenterol Hepatol. 2010;7:425-36.

30. Duffield JS. Cellular and molecular mechanisms in kidney fibrosis. J Clin Invest. 2014;124:2299-306.

31. Galligan $\mathrm{CL}$, Fish EN. The role of circulating fibrocytes in inflammation and autoimmunity. J Leukoc Biol. 2013;93:45-50

32. Varga JA, Trojanowska M. Fibrosis in systemic sclerosis. Rheum Dis Clin North Am. 2008;34(115-43):vii.
33. Wei J, Bhattacharyya S, Tourtellotte WG, Varga J. Fibrosis in systemic sclerosis: emerging concepts and implications for targeted therapy. Autoimmun Rev. 2011:10:267-75.

34. Kim KK, Kugler MC, Wolters PJ, Robillard L, Galvez MG, Brumwell AN, et al. Alveolar epithelial cell mesenchymal transition develops in vivo during pulmonary fibrosis and is regulated by the extracellular matrix. Proc Natl Acad Sci USA. 2006;103:13180-5.

35. Ho W-T, Chang J-S, Su C-C, Chang S-W, Hu F-R, Jou T-S, et al. Inhibition of matrix metalloproteinase activity reverses corneal endothelial-mesenchymal transition. Am J Pathol. 2015;185:2158-67.

36. Barbosa FL, Chaurasia SS, Cutler A, Asosingh K, Kaur H, de Medeiros FW, et al. Corneal myofibroblast generation from bone marrow-derived cells. Exp Eye Res. 2010;91:92-6.

37. Feller AC, Schneider H, Schmidt D, Parwaresch MR. Myofibroblast as a major cellular constituent of villous stroma in human placenta. Placenta. 1985:6:405-15.

38. Hinz B, Celetta G, Tomasek JJ, Gabbiani G, Chaponnier C. Alpha-smooth muscle actin expression upregulates fibroblast contractile activity. Mol Biol Cell. 2001;12:2730-41.

39. Dugina V, Fontao L, Chaponnier C, Vasiliev J, Gabbiani G. Focal adhesion features during myofibroblastic differentiation are controlled by intracellular and extracellular factors. J Cell Sci. 2001;114:3285-96.

40. Froese AR, Shimbori C, Bellaye P-S, Inman M, Obex S, Fatima S, et al. Stretch-induced activation of transforming growth factor- $\beta 1$ in pulmonary fibrosis. Am J Respir Crit Care Med. 2016;194:84-96.

41. Conti MA, Adelstein RS. Nonmuscle myosin II moves in new directions. J Cell Sci. 2008:121:11-8.

42. Matsumura S, Sakurai K, Shinomiya T, Fujitani N, Key K, Ohashi M. Biochemical and immunohistochemical characterization of the isoforms of myosin and actin in human placenta. Placenta. 2011;32:347-55.

43. Chiavegato A, Bochaton-Piallat ML, D'Amore E, Sartore S, Gabbiani G. Expression of myosin heavy chain isoforms in mammary epithelial cells and in myofibroblasts from different fibrotic settings during neoplasia. Virchows Arch Int J Pathol. 1995;426:77-86.

44. Tomasek JJ, Vaughan MB, Kropp BP, Gabbiani G, Martin MD, Haaksma CJ et al. Contraction of myofibroblasts in granulation tissue is dependent on Rho/Rho kinase/myosin light chain phosphatase activity. Wound Repair Regen. 2006;14:313-20.

45. Lecarpentier Y, Claes V, Lecarpentier E, Guerin C, Hébert J-L, Arsalane A, et al. Ultraslow myosin molecular motors of placental contractile stem villi in humans. PLoS ONE. 2014;9:e108814.

46. Lecarpentier E, Claes V, Timbely O, Hébert J-L, Arsalane A, Moumen A, et al. Role of both actin-myosin cross bridges and NO-cGMP pathway modulators in the contraction and relaxation of human placental stem villi. Placenta. 2013;34:1163-9.

47. Huszar G, Bailey P. Isolation and characterization of myosin in the human term placenta. Am J Obstet Gynecol. 1979;135:707-12.

48. Lecarpentier Y, Claes V, Hébert J-L, Krokidis X, Blanc F-X, Michel F, et al. Statistical mechanics of the human placenta: a stationary state of a near-equilibrium system in a linear regime. PLOS ONE. 2015;10:e0142471.

49. Starling EH. The linacre lecture on the law of the heart. Longmans: Green, \& Company; 1918.

50. Han J-C, Pham T, Taberner AJ, Loiselle DS, Tran K. Solving a century-old conundrum underlying cardiac force-length relations. Am J Physiol Heart Circ Physiol. 2019;316:H781-93.

51. Kuhtz-Buschbeck JP, Drake-Holland A, Noble MIM, Lohff B, Schaefer J. Rediscovery of Otto Frank's contribution to science. J Mol Cell Cardiol. 2018;119:96-103.

52. Sequeira $\mathrm{V}$, van der Velden J. The Frank-Starling Law: a jigsaw of titin proportions. Biophys Rev. 2017;9:259-67.

53. Toepfer CN, West TG, Ferenczi MA. Revisiting Frank-Starling: regulatory light chain phosphorylation alters the rate of force redevelopment (ktr) in a length-dependent fashion. J Physiol. 2016:594:5237-54.

54. Mou YA, Bollensdorff C, Cazorla O, Magdi Y, de Tombe PP. Exploring cardiac biophysical properties. Glob Cardiol Sci Pract. 2015:2015:10.

55. Hill AV. Thermodynamics of muscle. Nature. 1951;167:377-80.

56. Huxley AF. Muscle structure and theories of contraction. Prog Biophys Biophys Chem. 1957;7:255-318.

57. Lecarpentier Y, Claes V, Krokidis X, Hébert J-L, Timbely O, Blanc J-F, et al. Comparative statistical mechanics of muscle and non-muscle 
contractile systems: stationary states of near-equilibrium systems in a linear regime. Entropy. 2017;19:558.

58. Prigogine I, Nicolis G, Babloyantz A. Nonequilibrium problems in biological phenomena. Ann NY Acad Sci. 1974;231:99-105.

59. Lecarpentier Y, Krokidis X, Martin P, Pineau T, Hébert J-L, Quillard J, et al. Increased entropy production in diaphragm muscle of PPAR alpha knockout mice. J Theor Biol. 2008;250:92-102.

60. Onsager L. Reciprocal relations in irreversible processes. I. Phys Rev. 1931:37:405-26

61. Farley $A E$, Graham $\mathrm{CH}$, Smith $\mathrm{GN}$. Contractile properties of human placental anchoring villi. Am J Physiol Regul Integr Comp Physiol. 2004;287:R680-5.

62. Krantz KE, Panos TC, Evans J. Physiology of maternal-fetal relationship through the extracorporeal circulation of the human placenta. Am J Obstet Gynecol. 1962;83:1214-28.

63. Lecarpentier Y, Schussler O, Sakic A, Rincon-Garriz JM, Soulie P, Bochaton-Piallat M-L, et al. Human bone marrow contains mesenchymal stromal stem cells that differentiate in vitro into contractile myofibroblasts controlling T lymphocyte proliferation. Stem Cells Int. 2018:2018:6134787.

64. Bochaton-Piallat ML, Gabbiani G, Hinz B. The myofibroblast in wound healing and fibrosis: answered and unanswered questions. F1000Research. 2016. https://doi.org/10.12688/f1000research.8190.1.

65. Tyagi S, Gupta P, Saini AS, Kaushal C, Sharma S. The peroxisome proliferator-activated receptor: a family of nuclear receptors role in various diseases. J Adv Pharm Technol Res. 2011;2:236-40.

66. Juge-Aubry C, Pernin A, Favez T, Burger AG, Wahli W, Meier CA, et al. DNA binding properties of peroxisome proliferator-activated receptor subtypes on various natural peroxisome proliferator response elements. Importance of the 5'-flanking region. J Biol Chem. 1997;272:25252-9.

67. Lehrke M, Lazar MA. The many faces of PPARgamma. Cell. 2005:123:993-9.

68. Lakatos HF, Thatcher TH, Kottmann RM, Garcia TM, Phipps RP, Sime PJ. The role of PPARs in lung fibrosis. PPAR Res. 2007;2007:71323.

69. Picard F, Auwerx J. PPAR (gamma) and glucose homeostasis. Annu Rev Nutr. 2002:22:167-97.

70. Ahmadian M, Suh JM, Hah N, Liddle C, Atkins AR, Downes M, et al. PPARy signaling and metabolism: the good, the bad and the future. Nat Med. 2013;19:557-66.

71. Lecarpentier Y, Claes V, Hébert J-L. PPARs, cardiovascular metabolism, and function: near- or far-from-equilibrium pathways. PPAR Res. 2010 https://doi.org/10.1155/2010/783273.

72. Leask A. The contribution of peroxisome proliferator-activated receptor gamma to cutaneous wound healing. Adv Wound Care. 2013;2:69-73.

73. Burgess HA, Daugherty LE, Thatcher TH, Lakatos HF, Ray DM, Redonnet $M$, et al. PPARgamma agonists inhibit TGF-beta induced pulmonary myofibroblast differentiation and collagen production: implications for therapy of lung fibrosis. Am J Physiol Lung Cell Mol Physiol. 2005:288:L1146-53.

74. Tan JTM, McLennan SV, Song WW, Lo LW-Y, Bonner JG, Williams PF, et al. Connective tissue growth factor inhibits adipocyte differentiation. Am J Physiol Cell Physiol. 2008;295:C740-51.

75. Simon MF, Daviaud D, Pradère JP, Grès S, Guigné C, Wabitsch M et al. Lysophosphatidic acid inhibits adipocyte differentiation via lysophosphatidic acid 1 receptor-dependent down-regulation of peroxisome proliferator-activated receptor gamma2. J Biol Chem. 2005:280:14656-62.

76. Gong K, Xing D, Li P, Aksut B, Ambalavanan N, Yang Q, et al. Hypoxia induces downregulation of PPAR- $\gamma$ in isolated pulmonary arterial smooth muscle cells and in rat lung via transforming growth factor- $\beta$ signaling. Am J Physiol Lung Cell Mol Physiol. 2011;301:L899-907.

77. Dantas AT, Pereira MC, de Melo Rego MJB, da Rocha LF, da Pitta IR, Marques $\mathrm{CDL}$, et al. The role of PPAR gamma in systemic sclerosis. PPAR Res. 2015:2015:124624.

78. Ajuwon KM, Spurlock ME. Adiponectin inhibits LPS-induced NFkappaB activation and IL-6 production and increases PPARgamma2 expression in adipocytes. Am J Physiol Regul Integr Comp Physiol. 2005;288:R1220-5.

79. Abdelkarim M, Caron S, Duhem C, Prawitt J, Dumont J, Lucas A, et al. The farnesoid $X$ receptor regulates adipocyte differentiation and function by promoting peroxisome proliferator-activated receptor-gamma and interfering with the Wnt/beta-catenin pathways. J Biol Chem. 2010;285:36759-67.

80. Heuberger J, Birchmeier W. Interplay of cadherin-mediated cell adhesion and canonical Wnt signaling. Cold Spring Harb Perspect Biol. 2010;2:a002915.

81. Shtutman M, Zhurinsky J, Simcha I, Albanese C, D'Amico M, Pestell R, et al. The cyclin D1 gene is a target of the beta-catenin/LEF-1 pathway. Proc Natl Acad Sci USA. 1999;96:5522-7.

82. Angers S, Moon RT. Proximal events in Wnt signal transduction. Nat Rev Mol Cell Biol. 2009;10:468-77.

83. Moon RT, Kohn AD, De Ferrari GV, Kaykas A. WNT and beta-catenin signalling: diseases and therapies. Nat Rev Genet. 2004;5:691-701.

84. Vallée A, Lecarpentier Y, Guillevin R, Vallée J-N. Opposite interplay between the canonical WNT/ $\beta$-catenin pathway and PPAR gamma: a potential therapeutic target in gliomas. Neurosci Bull. 2018;34:573-88.

85. Vallée $A$, Lecarpentier Y. Crosstalk between peroxisome proliferatoractivated receptor gamma and the canonical WNT/ $\beta$-catenin pathway in chronic inflammation and oxidative stress during carcinogenesis. Front Immunol. 2018;9:745.

86. Baarsma HA, Spanjer AIR, Haitsma G, Engelbertink LHJM, Meurs $H$, Jonker MR, et al. Activation of WNT/ $\beta$-catenin signaling in pulmonary fibroblasts by TGF- $\beta_{1}$ is increased in chronic obstructive pulmonary disease. PLoS ONE. 2011;6:e25450.

87. Dees C, Distler JHW. Canonical Wnt signalling as a key regulator of fibrogenesis -implications for targeted therapies? Exp Dermatol. 2013:22:710-3.

88. Vallée A, Vallée J-N, Lecarpentier Y. PPARy agonists: potential treatment for autism spectrum disorder by inhibiting the canonical WNT/ $\beta$ catenin pathway. Mol Psychiatry. 2019;24(5):643-52.

89. Vallée A, Lévy BL, Blacher J. Interplay between the renin-angiotensin system, the canonical WNT/ $\beta$-catenin pathway and PPARY in hypertension. Curr Hypertens Rep. 2018;20:62.

90. Lam AP, Gottardi CJ. $\beta$-catenin signaling: a novel mediator of fibrosis and potential therapeutic target. Curr Opin Rheumatol. 2011;23:562-7.

91. Gustafson B, Eliasson B, Smith U. Thiazolidinediones increase the wingless-type MMTV integration site family (WNT) inhibitor Dickkopf-1 in adipocytes: a link with osteogenesis. Diabetologia. 2010;53:536-40.

92. Lu D, Carson DA. Repression of beta-catenin signaling by PPAR gamma ligands. Eur J Pharmacol. 2010;636:198-202.

93. Ross SE, Hemati N, Longo KA, Bennett CN, Lucas PC, Erickson RL, et al. Inhibition of adipogenesis by Wnt signaling. Science. 2000;289:950-3.

94. Kang S, Bennett CN, Gerin I, Rapp LA, Hankenson KD, Macdougald OA. Wht signaling stimulates osteoblastogenesis of mesenchymal precursors by suppressing CCAAT/enhancer-binding protein alpha and peroxisome proliferator-activated receptor gamma. J Biol Chem. 2007;282:14515-24

95. Bergmann C, Akhmetshina A, Dees C, Palumbo K, Zerr P, Beyer C, et al. Inhibition of glycogen synthase kinase $3 \beta$ induces dermal fibrosis by activation of the canonical Wnt pathway. Ann Rheum Dis. 2011;70:2191-8

96. Thomas PE, Peters-Golden M, White ES, Thannickal VJ, Moore BB. PGE(2) inhibition of TGF-beta1-induced myofibroblast differentiation is Smad-independent but involves cell shape and adhesion-dependent signaling. Am J Physiol Lung Cell Mol Physiol. 2007;293:L417-28.

97. Horowitz JC, Rogers DS, Sharma V, Vittal R, White ES, Cui Z, et al. Combinatorial activation of FAK and AKT by transforming growth factor-beta1 confers an anoikis-resistant phenotype to myofibroblasts. Cell Signal. 2007:19:761-71.

98. Parsons JT, Martin KH, Slack JK, Taylor JM, Weed SA. Focal adhesion kinase: a regulator of focal adhesion dynamics and cell movement. Oncogene. 2000;19:5606-13.

99. Parsons JT, Parsons SJ. Src family protein tyrosine kinases: cooperating with growth factor and adhesion signaling pathways. Curr Opin Cell Biol. 1997:9:187-92.

100. Lipfert L, Haimovich B, Schaller MD, Cobb BS, Parsons JT, Brugge JS. Integrin-dependent phosphorylation and activation of the protein tyrosine kinase pp125FAK in platelets. J Cell Biol. 1992;119:905-12.

101. Calalb MB, Polte TR, Hanks SK. Tyrosine phosphorylation of focal adhesion kinase at sites in the catalytic domain regulates kinase activity: a role for Src family kinases. Mol Cell Biol. 1995:15:954-63. 
102. Chen HC, Appeddu PA, Isoda H, Guan JL. Phosphorylation of tyrosine 397 in focal adhesion kinase is required for binding phosphatidylinositol 3-kinase. J Biol Chem. 1996;271:26329-34.

103. Thannickal VJ, Lee DY, White ES, Cui Z, Larios JM, Chacon R, et al. Myofibroblast differentiation by transforming growth factor-beta1 is dependent on cell adhesion and integrin signaling via focal adhesion kinase. J Biol Chem. 2003;278:12384-9.

104. Xia H, Nho RS, Kahm J, Kleidon J, Henke CA. Focal adhesion kinase is upstream of phosphatidylinositol 3-kinase/Akt in regulating fibroblast survival in response to contraction of type I collagen matrices via a beta 1 integrin viability signaling pathway. J Biol Chem. 2004;279:33024-34.

105. Verma A, Guha S, Wang H, Fok JY, Koul D, Abbruzzese J, et al. Tissue transglutaminase regulates focal adhesion kinase/AKT activation by modulating PTEN expression in pancreatic cancer cells. Clin Cancer Res. 2008;14:1997-2005.

106. Yamamoto T, Nakayama Y, Abe S. Expression of activin beta subunit genes in Sertoli cells of newt testes. Biochem Biophys Res Commun. 1996;224:451-6.

107. Coker RK, Laurent GJ, Jeffery PK, du Bois RM, Black CM, McAnulty RJ. Localisation of transforming growth factor beta1 and beta3 mRNA transcripts in normal and fibrotic human lung. Thorax. 2001;56:549-56.

108. Ludwicka A, Ohba T, Trojanowska M, Yamakage A, Strange C, Smith EA, et al. Elevated levels of platelet derived growth factor and transforming growth factor-beta 1 in bronchoalveolar lavage fluid from patients with scleroderma. J Rheumatol. 1995;22:1876-83.

109. Kulkarni AA, Thatcher TH, Olsen KC, Maggirwar SB, Phipps RP, Sime PJ. PPAR- $\gamma$ ligands repress TGF $\beta$-induced myofibroblast differentiation by targeting the PI3K/Akt pathway: implications for therapy of fibrosis. PLOS ONE. 2011;6:e15909.

110. Rosenbloom J, Castro SV, Jimenez SA. Narrative review: fibrotic diseases: cellular and molecular mechanisms and novel therapies. Ann Intern Med. 2010;152:159-66.

111. Deng $Y-L$, Xiong $X-Z$, Cheng N-S. Organ fibrosis inhibited by blocking transforming growth factor- $\beta$ signaling via peroxisome proliferatoractivated receptor $\gamma$ agonists. Hepatobiliary Pancreat Dis Int HBPD Int. 2012;11:467-78

112. Wei J, Bhattacharyya S, Varga J. Peroxisome proliferator-activated receptor $\gamma$ : innate protection from excessive fibrogenesis and potential therapeutic target in systemic sclerosis. Curr Opin Rheumatol. 2010;22:671-6.

113. Jeon K-I, Kulkarni A, Woeller CF, Phipps RP, Sime PJ, Hindman HB, et al. Inhibitory effects of PPARy ligands on TGF- $\beta 1$-induced corneal myofibroblast transformation. Am J Pathol. 2014;184:1429-45.

114. Wei J, Ghosh AK, Sargent JL, Komura K, Wu M, Huang Q-Q, et al. PPARY downregulation by TGFß in fibroblast and impaired expression and function in systemic sclerosis: a novel mechanism for progressive fibrogenesis. PLOS ONE. 2010;5:e13778.

115. Zheng S, Chen A. Disruption of transforming growth factor-beta signaling by curcumin induces gene expression of peroxisome proliferatoractivated receptor-gamma in rat hepatic stellate cells. Am J Physiol Gastrointest Liver Physiol. 2007;292:G113-23.

116. Wu M, Melichian DS, Chang E, Warner-Blankenship M, Ghosh AK, Varga J. Rosiglitazone abrogates bleomycin-induced scleroderma and blocks profibrotic responses through peroxisome proliferator-activated receptor-gamma. Am J Pathol. 2009;174:519-33.

117. Ghosh AK, Bhattacharyya S, Wei J, Kim S, Barak Y, Mori Y, et al. Peroxisome proliferator-activated receptor-gamma abrogates Smaddependent collagen stimulation by targeting the p300 transcriptional coactivator. FASEB J. 2009:23:2968-77.

118. Wei J, Zhu H, Komura K, Lord G, Tomcik M, Wang W, et al. A synthetic PPAR- $y$ agonist triterpenoid ameliorates experimental fibrosis: PPAR$\gamma$-independent suppression of fibrotic responses. Ann Rheum Dis. 2014;73:446-54.

119. Sun H, Berquin IM, Owens RT, O'Flaherty JT, Edwards IJ. Peroxisome proliferator-activated receptor gamma-mediated up-regulation of syndecan- 1 by $n-3$ fatty acids promotes apoptosis of human breast cancer cells. Cancer Res. 2008;68:2912-9.

120. Lam AP, Herazo-Maya JD, Sennello JA, Flozak AS, Russell S, Mutlu GM, et al. Wnt coreceptor Lrp5 is a driver of idiopathic pulmonary fibrosis. Am J Respir Crit Care Med. 2014;190:185-95.
121. Akhmetshina A, Palumbo K, Dees C, Bergmann C, Venalis P, Zerr P, et al. Activation of canonical Wnt signalling is required for TGF- $\beta$-mediated fibrosis. Nat Commun. 2012;3:735.

122. Blobe GC, Schiemann WP, Lodish HF. Role of transforming growth factor beta in human disease. N Engl J Med. 2000;342:1350-8.

123. Wynn TA. Cellular and molecular mechanisms of fibrosis. J Pathol. 2008:214:199-210.

124. Culver DA, Barna BP, Raychaudhuri B, Bonfield TL, Abraham S, Malur A, et al. Peroxisome proliferator-activated receptor gamma activity is deficient in alveolar macrophages in pulmonary sarcoidosis. Am J Respir Cell Mol Biol. 2004;30:1-5.

125. Miyahara T, Schrum L, Rippe R, Xiong S, Yee HF, Motomura K, et al. Peroxisome proliferator-activated receptors and hepatic stellate cell activation. J Biol Chem. 2000;275:35715-22.

126. Zheng F, Fornoni A, Elliot SJ, Guan Y, Breyer MD, Striker LJ, et al. Upregulation of type I collagen by TGF-beta in mesangial cells is blocked by PPARgamma activation. Am J Physiol Renal Physiol. 2002;282:F639-48.

127. Kapoor M, McCann M, Liu S, Huh K, Denton CP, Abraham DJ, et al. Loss of peroxisome proliferator-activated receptor gamma in mouse fibroblasts results in increased susceptibility to bleomycin-induced skin fibrosis. Arthritis Rheum. 2009;60:2822-9.

128. Zhao C, Chen W, Yang L, Chen L, Stimpson SA, Diehl AM. PPAR gamma agonists prevent TGFbeta1/Smad3-signaling in human hepatic stellate cells. Biochem Biophys Res Commun. 2006;350:385-91.

129. Zhao Y, Huang Y, He J, Li C, Deng W, Ran X, et al. Rosiglitazone, a peroxisome proliferator-activated receptor- $\gamma$ agonist, attenuates airway inflammation by inhibiting the proliferation of effector T cells in a murine model of neutrophilic asthma. Immunol Lett. 2014;157:9-15.

130. Hong KM, Belperio JA, Keane MP, Burdick MD, Strieter RM. Differentiation of human circulating fibrocytes as mediated by transforming growth factor-beta and peroxisome proliferator-activated receptor gamma. J Biol Chem. 2007;282:22910-20.

131. De Backer O, Elinck E, Priem E, Leybaert L, Lefebvre RA. Peroxisome proliferator-activated receptor gamma activation alleviates postoperative ileus in mice by inhibition of Egr-1 expression and its downstream target genes. J Pharmacol Exp Ther. 2009;331:496-503.

132. Marra F, Efsen E, Romanelli RG, Caligiuri A, Pastacaldi S, Batignani G, et al Ligands of peroxisome proliferator-activated receptor gamma modulate profibrogenic and proinflammatory actions in hepatic stellate cells. Gastroenterology. 2000;119:466-78.

133. Tan X, Dagher H, Hutton CA, Bourke JE. Effects of PPAR gamma ligands on TGF-beta1-induced epithelial-mesenchymal transition in alveolar epithelial cells. Respir Res. 2010;11:21.

134. Shafiei MS, Shetty S, Scherer PE, Rockey DC. Adiponectin regulation of stellate cell activation via PPARY-dependent and -independent mechanisms. Am J Pathol. 2011:178:2690-9.

135. Iglarz M, Touyz RM, Viel EC, Paradis P, Amiri F, Diep QN, et al. Peroxisome proliferator-activated receptor-alpha and receptor-gamma activators prevent cardiac fibrosis in mineralocorticoid-dependent hypertension. Hypertens Dallas Tex. 1979;2003(42):737-43.

136. Milam JE, Keshamouni VG, Phan SH, Hu B, Gangireddy SR, Hogaboam CM, et al. PPAR-gamma agonists inhibit profibrotic phenotypes in human lung fibroblasts and bleomycin-induced pulmonary fibrosis. Am J Physiol Lung Cell Mol Physiol. 2008;294:L891-901.

137. Uto H, Nakanishi C, Ido A, Hasuike S, Kusumoto K, Abe H, et al. The peroxisome proliferator-activated receptor-gamma agonist, pioglitazone, inhibits fat accumulation and fibrosis in the livers of rats fed a cholinedeficient, I-amino acid-defined diet. Hepatol Res. 2005:32:235-42.

138. Kiss E, Popovic ZV, Bedke J, Adams J, Bonrouhi M, Babelova A, et al. Peroxisome proliferator-activated receptor (PPAR)gamma can inhibit chronic renal allograft damage. Am J Pathol. 2010;176:2150-62.

139. Genovese T, Cuzzocrea S, Di Paola R, Mazzon E, Mastruzzo C, Catalano P, et al. Effect of rosiglitazone and 15-deoxy-Delta 12,14-prostaglandin J2 on bleomycin-induced lung injury. Eur Respir J. 2005;25:225-34.

140. White ES, Atrasz RG, Hu B, Phan SH, Stambolic V, Mak TW, et al. Negative regulation of myofibroblast differentiation by PTEN (Phosphatase and Tensin Homolog Deleted on chromosome 10). Am J Respir Crit Care Med. 2006;173:112-21.

141. Kuwano K. PTEN as a new agent in the fight against fibrogenesis. Am J Respir Crit Care Med. 2006:173:5-6. 
142. Reka AK, Kurapati H, Narala VR, Bommer G, Chen J, Standiford TJ, et al. Peroxisome proliferator-activated receptor-gamma activation inhibits tumor metastasis by antagonizing Smad3-mediated epithelial-mesenchymal transition. Mol Cancer Ther. 2010;9:3221-32.

143. Carthy JM, Garmaroudi FS, Luo Z, McManus BM. Wnt3a induces myofibroblast differentiation by upregulating TGF- $\beta$ signaling through SMAD2 in a $\beta$-catenin-dependent manner. PLoS ONE. 2011;6:e19809.

144. Bernard K, Logsdon NJ, Ravi S, Xie N, Persons BP, Rangarajan S, et al. Metabolic reprogramming is required for myofibroblast contractility and differentiation. J Biol Chem. 2015;290:25427-38.

145. Piersma B, Bank RA, Boersema M. Signaling in fibrosis: TGF- $\beta$, WNT, and YAP/TAZ converge. Front Med. 2015;2:59.

146. Mannaerts I, Leite SB, Verhulst S, Claerhout S, Eysackers N, Thoen LFR, et al. The Hippo pathway effector YAP controls mouse hepatic stellate cell activation. J Hepatol. 2015;63:679-88.

147. Lee M-J, Byun MR, Furutani-Seiki M, Hong J-H, Jung H-S. YAP and TAZ regulate skin wound healing. J Invest Dermatol. 2014;134:518-25.

148. Varelas X, Sakuma R, Samavarchi-Tehrani P, Peerani R, Rao BM, Dembowy J, et al. TAZ controls Smad nucleocytoplasmic shuttling and regulates human embryonic stem-cell self-renewal. Nat Cell Biol. 2008; 10:837-48

149. Fujii M, Nakanishi H, Toyoda T, Tanaka I, Kondo Y, Osada H, et al. Convergent signaling in the regulation of connective tissue growth factor in malignant mesothelioma: TGF $\beta$ signaling and defects in the Hippo signaling cascade. Cell Cycle. 2012;11:3373-9.

150. Azzolin L, Zanconato F, Bresolin S, Forcato M, Basso G, Bicciato S, et al. Role of TAZ as mediator of Wnt signaling. Cell. 2012:151:1443-56.

151. Azzolin L, Panciera T, Soligo S, Enzo E, Bicciato S, Dupont S, et al. YAP/ TAZ incorporation in the $\beta$-catenin destruction complex orchestrates the Wnt response. Cell. 2014;158:157-70.

152. Weiskirchen R, Weiskirchen S, Tacke F. Organ and tissue fibrosis: molecular signals, cellular mechanisms and translational implications. Mol Aspects Med. 2019:65:2-15.

153. Del Campo JA, Gallego P, Grande L. Role of inflammatory response in liver diseases: therapeutic strategies. World J Hepatol. 2018:10:1-7.

154. Piera-Velazquez S, Mendoza FA, Jimenez SA. Endothelial to mesenchymal transition (EndoMT) in the pathogenesis of human fibrotic diseases. J Clin Med. 2016;5:45.
155. Douillet CD, Velarde V, Christopher JT, Mayfield RK, Trojanowska ME, Jaffa AA. Mechanisms by which bradykinin promotes fibrosis in vascular smooth muscle cells: role of TGF-beta and MAPK. Am J Physiol Heart Circ Physiol. 2000;279:H2829-37.

156. Kazlauskas A. PDGFs and their receptors. Gene. 2017;614:1-7.

157. Drakopanagiotakis F, Wujak L, Wygrecka M, Markart P. Biomarkers in idiopathic pulmonary fibrosis. Matrix Biol J Int Soc Matrix Biol. 2018;68-69:404-21

158. Loomba R, Lawitz E, Mantry PS, Jayakumar S, Caldwell SH, Arnold H, et al. The ASK1 inhibitor selonsertib in patients with nonalcoholic steatohepatitis: a randomized, phase 2 trial. Hepatology. 2018;67:549-59.

159. Hardy T, Zeybel M, Day CP, Dipper C, Masson S, McPherson S, et al. Plasma DNA methylation: a potential biomarker for stratification of liver fibrosis in non-alcoholic fatty liver disease. Gut. 2017;66:1321-8.

160. Yazdani S, Bansal R, Prakash J. Drug targeting to myofibroblasts: implications for fibrosis and cancer. Adv Drug Deliv Rev. 2017;121:101-16.

161. Bartneck M, Warzecha KT, Tacke F. Therapeutic targeting of liver inflammation and fibrosis by nanomedicine. Hepatobiliary Surg Nutr. 2014;3:364-76.

162. Nastase MV, Zeng-Brouwers J, Wygrecka M, Schaefer L. Targeting renal fibrosis: mechanisms and drug delivery systems. Adv Drug Deliv Rev. 2018;129:295-307.

163. Hao S, He W, Li Y, Ding H, Hou Y, Nie J, et al. Targeted inhibition of $\beta$-catenin/CBP signaling ameliorates renal interstitial fibrosis. J Am Soc Nephrol JASN. 2011;22:1642-53.

164. Rice LM, Padilla CM, McLaughlin SR, Mathes A, Ziemek J, Goummih $\mathrm{S}$, et al. Fresolimumab treatment decreases biomarkers and improves clinical symptoms in systemic sclerosis patients. J Clin Invest. 2015;125:2795-807.

\section{Publisher's Note}

Springer Nature remains neutral with regard to jurisdictional claims in published maps and institutional affiliations.

Ready to submit your research? Choose BMC and benefit from:

- fast, convenient online submission

- thorough peer review by experienced researchers in your field

- rapid publication on acceptance

- support for research data, including large and complex data types

- gold Open Access which fosters wider collaboration and increased citations

- maximum visibility for your research: over $100 \mathrm{M}$ website views per year

At BMC, research is always in progress.

Learn more biomedcentral.com/submissions 